\title{
FAKTOR-FAKTOR YANG MEMPENGARUHI KUNJUNGAN WISATAWAN KE OBJEK WISATA SYARIAH DI SUMATERA BARAT
}

\author{
Oleh \\ ${ }^{1)}$ Nuryenti Lisma, ${ }^{2)}$ Sepris Yonaldi, SE., MM, ${ }^{3)}$ Liza Zulbahri, SE., MM \\ ${ }^{1,2,3)}$ Fakultas Ekonomi Universitas Tamansiswa Padang \\ Lismanuryenti@gmail.com, seprisyonaldi@gmail.com, lizazulbahri@yahoo.com
}

\begin{abstract}
Abstrak
Penelitian ini digunakan untuk mengetahui seberapa besar pengaruh faktor-faktor yang mempengaruhi kunjungan wisatawan ke objek wisata syariah di Sumatera Barat. Metode penelitian yang digunakan adalah kuantitatif deskriptifdengan teknik purposive sampling. Sampel yang digunakan adalah 100 responden, instrumen yang digunakan dalam penelitian ini adalah kuesioner/angket. Dari uji t yang dilakukan didapatkan dua variabel berpengaruh signifikan terhadap kunjungan wisatawan pada objek wisata syariah Sumatera Barat yaitu variabel pelayanan $\left(\mathrm{X}_{2}\right)$, kepuasan $\left(\mathrm{X}_{3}\right)$ dan terdapat satu variabel yang tidak berpengaruh signifikan terhadap kunjungan wisatawan ke objek wisata syariah Sumatera Barat yaitu promosi $\left(\mathrm{X}_{1}\right)$. Dari hasil uji $\mathrm{F}$ terbukti bahwa variabel promosi $\left(\mathrm{X}_{1}\right)$, pelayanan $\left(\mathrm{X}_{2}\right)$, dan kepuasan $\left(\mathrm{X}_{3}\right)$ secara bersama-sama berpengaruh signifikan terhadap kunjungan wisatawan ke objek wisata syariah Sumatera Barat.Hasil koefisien determinasi didapatkan $65,1 \%$, sedangkan sisanya 34,9\% dipengaruhi oleh variabel lain yang tidak dibahas dalam penelitian ini seperti kondisi ekonomi dan prilaku konsumen diantaranya pribadi, sosial, dan budaya.
\end{abstract}

\section{Kata Kunci : Promosi, Pelayanan, Kepuasan dan Kunjungan Wisatawan.}

\section{PENDAHULUAN}

\section{Latar Belakang Masalah}

Industri pariwisata mengalami perkembangan yang sangat pesat saat ini. Industri pariwisata sangat sensitif terhadap perubahan yang terjadi, baik secara internal maupun eksternal yang juga memberikan pengaruhi oleh jumlah dan minat wisatawan untuk mengunjungi suatu negara, wilayah/provinsi maupun daerah. Menurut Crecentrating, Halal Friendly Travel and Tourism Consultant, dalam (Sugiarti, 2015) menjelaskan bahwa potensi terhadap pasar untuk pengembangan wisata syariah (muslim) jika dilihat dari populasi muslim di dunia sebanyak 1,8 milyar atau sekitar $28 \%$ dari total populasi dunia sebesar 6,4 milyar yang tersebar di 148 negara. Dari total muslim di dunia, sebesar $62 \%$ berasal dari Asia Pasifik atau dengan jumlah 972.000.000 orang, sehingga wisata syariah (halal tourism) menjadi trend dari pariwisata saat ini. Wisatawan syariah harus dianggap sebagai segmen penting dari industri pariwisata, karena dapat memenuhi kebutuhan keagamaan dan kebutuhan entertaiment yang sesuai syariah Islam. Wisata syariah yang lebih memfokuskan konsep pariwisata Islam 
Jurnal Manajemen dan Kewirausahaan, Volume 8, Nomor 1, Januari 2016 ISSN 2086 - 5031

dengan menyediakan produk yang halal, bukan hanya dinikmati oleh wisatawan muslim semata. Bagi wisatawan nonmuslim, wisata syariah merupakan salah satu solusi untuk menciptakan pengalaman liburan yang menyenangkan untuk keluarga sekaligus aman dari pengaruh-pengaruh negatif yang kerap di temui di tempat-tempat hiburan ketika berwisata. (Toeman, 2011) Wisata syariah adalah aktivitas wisata yang dilakukan oleh muslim yang memang didorong oleh motivasi untuk melakukan aktivitas Islam dan sesuai prinsip syariah.

Kuatnya budaya Islam yang ada di Sumatera Barat merupakan salah satu faktor yang menjadi pertimbangan penetapan Sumatera Barat sebagai daerah tujuan wisata halal yang memberikan daya tarik tersendiri bagi wisatawan untuk berkunjung ke Sumatera Barat. Penetapan Sumatera Barat sebagai daerah pengembangan wisata halal di Indonesia pada tanggal 12 Mei 2016, merupakan suatu langkah yang baik untuk memajukan pariwisata Sumatera Barat dan menjadi contoh bagi daerah lain yang ingin menetapkan kebijakan wisata halal. Banyak masyarakat yang belum mengetahui tentang wisata halal, bahkan wisata halal masih asing terdengar oleh masyarakat awam. Pada umumnya masyarakat yang mengira bahwa wisata halal sama dengan wisata religi, wisata halal berbeda dengan wisata religi. Wisata religi contohnya seperti ziarah ke makam para Nabi dan juga umroh. Sedangkan, wisata halal sangat mengedepankan produk-produk halal dan aman dikonsumsi wisatawan yang berkunjung ke objek wisata tersebut. Namun, bukan berarti wisatawan non-muslim tidak bisa menikmati wisata halal. Bagi yang nonmuslim, wisata halal dengan produk halal ini adalah jaminan sehat. Karena pada prinsipnya, implementasi kaidah syariah itu berarti menyingkirkan hal-hal yang membahayakan bagi kemanusiaan dan lingkungannya dalam produk maupun jasa yang diberikan, dan tentu memberikan kebaikan. Dengan nilai-nilai keislaman yang ada pada pariwisata halal bukan hanya bermanfaat bagi industri pariwisata tetapi juga bermanfaat bagi masyarakat dalam meningkatkan keimanan, menjadi manusia yang lebih baik dan mencegah terjadinya hal yang bersifat mudharat bagi masyarakat (Sofyan, 2012).

Provinsi Sumatera Barat merupakan salah satu sektor yang strategis dan potensial untuk dikembangkan, mengingat potensi obyek wisata syariah yang dimiliki Provinsi Sumatera Barat sangat beragam meliputi: keindahan Danau Singkarak, Danau Maninjau, Danau Kembar, Ngarai Sianok, Lubang Jepang, 
Jurnal Manajemen dan Kewirausahaan, Volume 8, Nomor 1, Januari 2016 ISSN 2086 - 5031

Pulau Cubadak, Lembah Anai, Istana Pagaruyung, Kepulauan Mentawai, Pantai Padang dan masih banyak lagi objek wisata halal lainnya yang ada di Sumatera Barat, (Sumbarprov, 2016)

Berdasarkan hal tersebut maka penulis termotivasi untuk melakukan penelitian tentang dunia pariwisata halal atau pariwisata syariah dan berkaitan dengan jumlah kunjungan wisatawan halal di Sumatera Barat. Hal ini di sebabkan Sumatera Barat memiliki banyak tempat wisata halal dan rekreasi yang mendukung untuk mengembangkan wisata halal khususnya peninggalan sejarah yang menjadi ciri khas Sumatera Barat saat ini.

Ketatnya persaingan dalam dunia pariwisata menyebabkan setiap tempat wisata berusaha menonjolkan keunggulan yang mereka miliki dan tentunya dengan memberikan pelayanan yang baik. Jika wisatawan merasa pelayanan baik, maka akan membuat wisatawan merasa senang dan puas, khususnya di Sumatera Barat. Tempat wisata di Sumatera Barat saat ini selalu bertambah terutama pariwisata bahari yang sangat diminati para wisatawan. Wisata halal di Sumatra Barat merupakan ikon wisata terbaru, dengan destinasi wisata yang memiliki view yang sangat berbeda dan sangat nyaman untuk wisatawan, supaya wisatawan nusantara maupun mancanegara berminat untuk datang ke Sumatera Barat. Berdasarkan latar belakang tersebut, maka peneliti tertarik melakukan penelitian dengan judul "Faktor-Faktor Yang Mempengaruhi Kunjungan Wisatawan Ke Objek Wisata Syariah (Halal Tourism) di Sumatera Barat".

\section{Tujuan Penelitian}

Adapun tujuan dari penelitian ini adalah :

1. Untuk mengetahui dan menganalisa secara parsial pengaruh promosi terhadap kunjungan wisatawan ke objek Wisata Syariah (Halal Tourism) di Sumatera Barat

2. Untuk mengetahui dan menganalisa secara parsial pengaruh pelayanan terhadap kunjungan wisatawan ke objek Wisata Syariah (Halal Tourism) di Sumatera Barat

3. Untuk mengetahui dan menganalisa secara parsial pengaruh kepuasan terhadap kunjungan wisatawan ke objek Wisata Syariah (Halal Tourism) di Sumatera Barat

4. Untuk mengetahui dan menganalisa secara simultan pengaruh promosi, pelayanan dan kepuasan terhadap kunjungan wisatawan ke objek Wisata Syariah (Halal Tourism) di Sumatera Barat 


\section{II.LANDASAN TEORI}

\section{Promosi}

\section{Pengertian Promosi}

Kotler

dan

Keller(2009:510),menyatakan bahwa promosi adalah berbagai cara untuk menginformasikan, membujuk, dan mengingatkan konsumen secara langsung maupun tidak langsung tentang suatu produk atau brand yang dijual. Menurut Alma (2014:179), promosi adalah sejenis komunikasi yang memberi penjelasan yang meyakinkan calon konsumen tentang barang atau jasa. Tujuan promosi ialah memperoleh perhatian, mendidik, mengingatkan, dan meyakinkan calon konsumen.

Promosi tempat tujuan wisata sangat diperlukan oleh daerah-daerah yang memiliki banyak potensi di tanah air. Tentunya upaya kegiatan ini menjadi sangat penting dalam kerangka penyelenggaraan otonomi daerah $\mathrm{di}$ Indonesia sampai kepada Pemerintahan Daerah Tingkat II. Promosi tempat wisata yang dirancang dengan baik akan memberikan tambahan penerimaan asli daerah, dan mendorong proses multiplier perkembangan ekonomi lokalitas di sekitar daerah tujuan wisata.

\section{Indikator Promosi}

Menurut Kotler dan Keller (2009), untuk mengukur promosi digunakan indikator sebagai berikut :

1. Iklan (Adveristing)

Iklan merupakan bentuk promosi dengan menggunakan media cetak dan elektronik. Iklan selama ini dipandang sebagai bentuk promosi yang paling efektif. Iklan merupakan pesan-pesanpenjualan yang paling persuasif yang diarahkan kepadapara calon pembeli yang paling potensial atas produk barang atau jasa tertentu dengan biaya semurah murahnya. Iklan dapat mempengaruhi dua parameter.

2. Promosi penjualan (Sales Promotion)

Promosi penjualan pada dasarnya memberikan insentif kepada konsumen untuk membeli produkproduk yang ditawarkan. Bentukbentuk insentifnya meliputi pemberian diskon atau potongan harga dan hadiah langsung serta mengikut sertakan pembeli kedalam suatu undian yang berhadiah besar.

\section{Publisitas (Public Relation)}

Publisitas yang digunakan bersama dengan cara mensponsori kegiatankegiatan tertentu dalam masyarakat seperti olah raga dan kesenian. 
Jurnal Manajemen dan Kewirausahaan, Volume 8, Nomor 1, Januari 2016

ISSN 2086 - 5031

Walaupun efektivitas

seringdipertanyakan, namun dapat digunakan sebagai sarana untukmendekatkan diri kepada masyarakat atau konsumen.

\section{Pelayanan}

\section{Pengertian Pelayanan}

Layanan/jasa menurut Kotler dan Keller(2009:65) adalah setiap tindakan atau kinerja yang dapat ditawarkan satu pihak kepada pihak lain yang pada intinya tidak berwujud dan tidak menghasilkan kepemilikan apapun. Pengertian pelayanan dalam Kamus Besar Bahasa Indonesia di sebutkan bahwa pelayanan adalah membantu menyiapkan (mengurus) apa yang diperlukan seseorang. Sedangkan menurut Moenir (2010), pelayanan adalah kegiatan yang dilakukan oleh seseorang atau sekelompok orang dengan landasan faktor materi melalui sistem, prosedur dan metode tertentu dalam rangka usaha memenuhi kepentingan orang lain sesuai dengan haknya.

Jadi dapat disimpulkan bahwa pelayanan dalam pariwisata itu tidak terwujud namun sangat erat hubungannya dengan jumlah kunjungan wisatawan, karena semakin baik pelayanan di tempat suatu objek wisata maka kunjuungan wisatawan akan meningkat dan wisatawan akan melakukan kunjungan ulang ke objek wisata tersebut.

\section{Indikator Pelayanan}

Menurut Kotler dan Keller (2009:52), terdapat lima determinan kualitas pelayanan yang dapat dirincikan sebagai berikut:

1. Keandalan (Reliability)

Kemampuan untuk melaksanakan pelayanan yang dijanjikan dengan dengan andal dan akurat.

2. Daya tangkap (Responsiveness)

Kesediaan membantu pelanggan dan memberikan layanan tepat waktu.

3. Jaminan (Assuranse)

Pengetahuan dan kesopanan karyawan serta kemampuan mereka untuk menunjukan kepercayaan dan keyakinan.

4. Empati (Empaty)

Kondisi memperhatikan dan memberikan perhatian pribadi kepada pelanggan.

5. Berwujud (Tangibles)

Penampilan fasilitas fisik, peralatan, personal, dan bahan berkomunikasi.

\section{Kepuasan}

\section{Pengertian Kepuasan}

Kepuasan adalah tingkat perasaan seseorang setelah membandingkan (kinerja atau hasil) yang dirasakan 
Jurnal Manajemen dan Kewirausahaan, Volume 8, Nomor 1, Januari 2016

ISSN 2086 - 5031

dibandingkan dengan harapannya.

Konsumen dapat mengalami salah satu dari tiga tingkat kepuasan umum yaitu kalau kinerja dibawah harapan, konsumen akan merasa kecewa tetapi jika kinerja sesuai dengan harapan, pelanggan akan merasa puas dan apabila kinerja bisa melebihi harapan pelanggan akan merasa sangat puas senang atau gembira (Kotler dan Amstrong, 2013). Pada dasarnya tujuan dari suatu bisnis adalah untukmenciptakan para pelanggan yang merasa puas. Terciptanya kepuasan pelanggan dapat memberikan beberapa manfaat diantaranya hubungan antara perusahaan dan pelanggan menjadi harmonis, memberikan dasar yang baik bagi pembelian ulang dan terciptanya loyalitas pelangggan dan membentuk suatu rekomendasi dari mulut ke mulut (word of mouth) yang menguntungkan bagi perusahaan (Tjiptono, 2008:24).

Kotler (2010:13) mengenai kepuasan pelanggan adalah the extent to which a product's perceived performance matches a buyers expectation. Kepuasan pelanggan adalah tingkat dimana suatu pencapaian performa dari sebuah produk yang diterima oleh konsumen sama dengan ekspektasi konsumen itu sendiri.

\section{Indikator Kepuasan}

Menurut teori Kotler dan Amstrong (2013), bahwa kunci untuk mempertahankan pelanggan adalah kepuasan konsumen. Adapun yang menjadi indikator dalam penelitian ini adalah:

1. Membeli kembali (re-purchase)

Dimana pelanggan akan kembali ke perusahaan untuk mencari barang atau jasa.

2. Menciptakan word-of mouth

Dalam hal ini, pelanggan akan mengatakan hal-hal yang baik tentang perusahaan kepada orang lain.

3. Menciptakan merek

Pelanggan akan kurang memperhatikan merek dan iklan dari produk pesaing.

4. Konfirmasi harapan

Kesesuaian atau ketidaksesuaian terhadap harapan konsumen saat berkunjung.

\section{III.METODOLOGI PENELITIAN}

\section{Jenis Metodologi Penelitian}

Metodologi penelitian yang digunakan dalam penelitian ini adalah penelitian kuantitatif. 


\section{Populasi dan Sampel Penelitian}

\section{Populasi Penelitian}

Dalam penelitian ini yang menjadi populasi adalah seluruh wisatawan yang mengunjungi objek wisata syariah (halal tourism) di Sumatera Barat meliputi: keindahan Danau Singkarak, Danau Maninjau, Danau Kembar, Ngarai Sianok, Lubang Jepang, Pulau Cubadak, Lembah Anai, Istana Pagaruyung, Kepulauan Mentawai dan Pantai Padang. Oleh karena itu, tidak dapat diketahui secara pasti ukuran populasi sebenarnya dari konsumen yang datang ke objek wisata syariah di Sumatera Barat.

\section{Sampel Penelitian}

dalam penelitian ini digunakan 100 responden sebagai sampel, dengan kriteria responden merupakan wisatawan Muslim yang sedang dan pernah berkunjung ke objek wisata syariah Sumatera Barat.

Adapun yang menjadi kriteria suatu objek wisata dikatakan sebagai objek wisata syariah adalah:

1. Pelayanan yang diberikan kepada wisatawan sesuai dengan prinsip dan aturan islam secara keseluruhan.

2. Semua kegiatan sesuai dengan prinsip-prinsip dan aturan islam
3. Restoran/rumah makan harus mengikuti standar pelayanan yang halal begitupun dengan makanan dan minuman sesuai dengan aturan islam.

4. Adanya tempat-tempat yang disediakan untuk semua wisatawan muslim melakukan kegiatan keagamaan, seperti tempat ibadah, air bersih, tempat berwudu', dan lain sebagainya.

5. Seluruh fasilitas yang disediakan di objek wisata sesuai dengan prinsip islam.

Berdasarkan kriteria diatas, maka penulis mengambil sampel objek wisata syariah di Sumatera Barat antara lain : Danau Singkarak, Danau Kembar, Ngarai Sianok, Lubang Jepang, Lembah Anai, Istana Pagaruyung dan Pantai Padang. Hal ini dikarenakan keterbatasan waktu, biaya, serta lokasi yang terlalu jauh dari tempat tinggal peneliti.

\section{HASIL PENELITIAN DAN PEMBAHASAN}

\section{Hasil Analisis Regresi}

\section{Uji Regresi Linier Berganda}

Berdasarkan analisis data dengan menggunakan program SPSS 16.00 for windows, maka diperoleh hasil persamaan regresi sebagai berikut: 
Jurnal Manajemen dan Kewirausahaan, Volume 8, Nomor 1, Januari 2016 ISSN 2086 - 5031

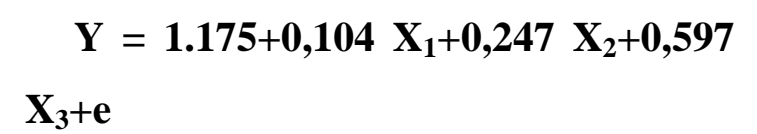

Dimana:
$\mathrm{Y}=$ Variabel terikat (kunjungan wisatawan)
$\mathrm{a}=$ Konstanta
$\mathrm{X}_{1}=$ Promosi
$\mathrm{X}_{2}$ = Pelayanan
$\mathrm{X}_{3}=$ Kepuasan
$\mathrm{e} \quad=$ Standar Error

Persamaan regresi diatas memperlihatkan hubungan antara variabel independen dengan variabel dependen secara parsial, dari persaman tersebut dapat diambil kesimpulan bahwa :

1. Nilai constanta adalah $=1.175$, artinya jika tidak terjadi perubahan variabel promosi $\left(\mathrm{X}_{1}\right)$, pelayanan $\left(\mathrm{X}_{2}\right)$, kepuasan $\left(\mathrm{X}_{3}\right)\left(\right.$ nilai $\mathrm{X}_{1}, \mathrm{X}_{2}$ dan $X_{3}$ adalah 0) maka kunjungan wisatawan ke objek wisata syariah Sumatera Barat tetap 1.175 satuan.

2. Nilai koefisien regresipromosi $\left(\mathrm{X}_{1}\right)$ adalah $=0,104$ artinya jika variabel promosi $\left(\mathrm{X}_{1}\right)$ meningkat sebesar 1 (satuan) dengan asumsi variabel pelayanan $\left(\mathrm{X}_{2}\right)$, variabel kepuasan $\left(\mathrm{X}_{3}\right)$ dan konstanta (a) adalah 0 (nol), maka kunjungan wisatawan ke objek wisata syariah Sumatera Barat meningkat sebesar 0,104 satuan
3. Nilai koefisien regresi pelayanan $\left(\mathrm{X}_{2}\right)$ adalah $=0,247$ artinya jika variabel pelayanan $\left(\mathrm{X}_{2}\right)$ meningkat sebesar 1 (satuan) dengan asumsi variabel promosi $\left(\mathrm{X}_{1}\right)$ dan kepuasan $\left(\mathrm{X}_{3}\right)$ dan konstanta (a) adalah 0 (nol), maka maka kunjungan wisatawan ke objek wisata syariah Sumatera Barat meningkat sebesar 0,247 satuan

4. Nilai koefisien regresi kepuasan $\left(\mathrm{X}_{3}\right)$ adalah $=0,597$ artinya jika variabel kepuasan $\left(\mathrm{X}_{3}\right)$ meningkat sebesar 1 (satuan) dengan asumsi variabel promosi $\left(\mathrm{X}_{1}\right)$ dan pelayanan $\left(\mathrm{X}_{2}\right)$ dan konstanta (a) adalah 0 (nol), maka maka kunjungan wisatawan ke objek wisata syariah Sumatera Barat meningkat sebesar 0,597 satuan

\section{Uji t-Statistik}

Berdasarkan hasil yang didapat, bisa dijelaskan sebagai berikut :

\section{Pengaruh Variabel promosi} terhadap kunjungan wisatawan ( $\left.\mathbf{H}_{1}\right)$

Variabel promosi $\left(\mathrm{X}_{1}\right)$ tidak berpengaruh secara signifikan terhadap kunjungan wisatawan ke objek wisata syariah Sumatera Barat. Hal ini terlihat dari signifikan $0,287>0,05$, dan nilai $t_{\text {tabel }} \mathrm{df}=\mathrm{n}-\mathrm{k}$ $=100-4=96(1,660)$ berarti nilai 
Jurnal Manajemen dan Kewirausahaan, Volume 8, Nomor 1, Januari 2016

ISSN 2086 - 5031

$\mathrm{t}_{\text {hitung }}<\mathrm{t}_{\text {tabel }}(1,070<1,660)$, maka

Ho diterima dan $\mathrm{H}_{1}$ ditolak.

2. Pengaruh

pelayananterhadap

wisatawan $\left(\mathrm{H}_{2}\right)$

Variabel pelayanan $\left(\mathrm{X}_{2}\right)$ berpengaruh secara signifikan terhadap kunjungan wisatawan ke objek wisata syariah Sumatera Barat. Hal ini terlihat dari signifikan $0,001<$ 0,05 , dan nilai $\mathrm{t}_{\text {tabel }} \mathrm{df}=\mathrm{n}-\mathrm{k}=100-4$ $=96(1,660)$ berarti nilai $t_{\text {hitung }}>t_{\text {tabel }}$ (3,276> 1,660), maka Ho ditolak dan $\mathrm{H}_{2}$ diterima.

\section{Pengaruh}

Variabel

kepuasanterhadap kunjungan wisatawan $\left(\mathrm{H}_{3}\right)$

Variabel kepuasan $\left(\mathrm{X}_{3}\right)$ berpengaruh secara signifikan terhadap kunjungan wisatawan ke objek wisata syariah Sumatera Barat. Hal ini terlihat dari signifikan $0,000<$ 0,05 , dan nilai $\mathrm{t}_{\text {tabel }} \mathrm{df}=\mathrm{n}-\mathrm{k}=100-4$ $=96(1,660)$ berarti nilai $t_{\text {hitung }}>t_{\text {tabel }}$ (5,723> 1,660), maka Ho ditolak dan $\mathrm{H}_{3}$ diterima

\section{Uji F-Statistik}

Berdasarkan hasil pengujian pada tabel diatas dapat dilihat pada nilai $\mathrm{F}_{\text {hitung }}$ sebesar 62,544 dengan nilai $\mathrm{F}_{\text {tabel }}$ $d f_{1}=\mathrm{k}-1(4-1=3), d f_{2}=\mathrm{n}-\mathrm{k}(100-4=\quad 96)$ adalah 2.70 sehingga nilaiF $_{\text {hitung }}>$
$\mathrm{F}_{\text {tabelatau62,544 }}>2.70$,dan tingkat signifikan $0,000<0,05$, maka Ho ditolak dan Ha diterima, dapat disimpulkan bahwa variabel $\operatorname{promosi}\left(\mathrm{X}_{1}\right) \quad$ dan variabel pelayanan $\left(\mathrm{X}_{2}\right)$ dan variabel kepuasan $\left(\mathrm{X}_{3}\right)$ secara bersamaan berpengaruh signifikan terhadap kunjungan wisatawan ke objek wisata syariah Sumatera Barat.

\section{Uji Koefisien Determinasi}

Berdasarkan ringkasan hasil analisis koefisien determinasi seperti yang dikemukakan pada tabel 4.20diketahui bahwa nilai koefisien determinasi terdapat pada nilaiAdjusted RSquare, adalah 0,651 berarti sekitar $65,1 \%$, variabel promosi $\left(\mathrm{X}_{1}\right)$, variabel pelayanan $\left(\mathrm{X}_{2}\right)$ dan variabel kepuasan $\left(\mathrm{X}_{3}\right)$ secara bersamaan mempengaruhi variabelkunjungan wisatawan ke objek wisata syariah Sumatera Barat, sedangkan sisanya $34,9 \%$ dipengaruhi oleh variabel lain yang tidak dibahas dalam penelitian ini seperti kondisi ekonomi dan prilaku konsumen diantaranya pribadi, sosial, dan budaya (Kotler dan Keller, 2008).

Pembahasan Hasil Analisis Penelitian

Berdasarkan analisa data mengenai pengaruh variabel 
Jurnal Manajemen dan Kewirausahaan, Volume 8, Nomor 1, Januari 2016

ISSN 2086 - 5031

$\operatorname{promosi}\left(\mathrm{X}_{1}\right)$, variabel pelayanan $\left(\mathrm{X}_{2}\right)$ dan variabel kepuasan $\left(\mathrm{X}_{3}\right)$ serta secara individu dan secara bersamaan terhadap kunjungan wisatawan ke objek wisata syariah Sumatera Barat, maka pembahasan hasilnya adalah sebagai berikut:

\section{Pengaruh Variabel promosi} $\left(\mathbf{X}_{1}\right)$ terhadap kunjungan wisatawan $\left(\mathbf{H}_{1}\right)$

Dari hasil analisis uji hipotesa pada tingkat kepercayaan $\alpha=5 \%$ terbukti bahwa variabel promosi $\left(\mathrm{X}_{1}\right)$ tidak berpengaruh signifikan terhadap kunjungan wisatawan ke objek wisata syariah Sumatera Barat. Hal ini disebabkan karena pada saat ini pengunjung wisata syariah di sumatera Barat hanya di dominasi oleh masyarakat lokal yang kedatangannya didasari tempat tinggal yang dekat dengan objek wisata, serta promosi yang dilakukan terhadap tempat wisata syariah belum maksimal.

\section{Pengaruh Variabel pelayanan}

$\left(\mathrm{X}_{2}\right)$ terhadap
wisatawan $\left(\mathrm{H}_{2}\right)$

Dari hasil analisis uji hipotesa pada tingkat kepercayaan $\alpha=5 \%$ terbukti bahwavariabel pelayanan $\left(\mathrm{X}_{2}\right)$ berpengaruh secara signifikan terhadap kunjungan wisatawan ke objek wisata syariah Sumatera Barat. Hal ini disebabkan karena pihak pengelola telah memberikan pelayanan yang maksimal kepada pengunjung, yang pada dasarnya pengunjung telah merasa aman, nyaman dan tentram akan pelayanan yang diberikan oleh pengelola dan juga masyarakat yang berada di sekitar objek wisata syariah Sumatera Barat.

\section{Pengaruh Variabel kepuasan $\left(X_{3}\right)$ terhadap kunjungan wisatawan $\left(\mathbf{H}_{3}\right)$}

Dari hasil analisis uji hipotesa pada tingkat kepercayaan $\alpha=5 \%$ terbukti bahwa variabel kepuasan $\left(\mathrm{X}_{3}\right)$ berpengaruh secara signifikan terhadap kunjungan wisatawan ke objek wisata syariah Sumatera BaratDengan adanya sarana dan prasarana, serta pelayanan yang maksimal dari pihak pengelola dan masyarakat sekitar objek wisata syariah, membuat pengunjung betah, aman dan nyaman saat berada di objek wisata syariah tersebut, sehingga menimbulkan rasa kepuasan dan keinginan yang kuat untuk berkunjung kembali ke objek wisata syariah Sumatera Barat.

4. Pengaruh variabel promosi $\left(X_{1}\right)$, pelayanan $\left(X_{2}\right)$ dan kepuasan $\left(X_{3}\right)$ 
Jurnal Manajemen dan Kewirausahaan, Volume 8, Nomor 1, Januari 2016

ISSN 2086 - 5031

terhadap kunjungan wisatawan (Y).

Dari hasil uji $\mathrm{F}$ terbukti bahwa variabel promosi $\left(\mathrm{X}_{1}\right)$, pelayanan $\left(\mathrm{X}_{2}\right)$ dan variabel kepuasan $\left(\mathrm{X}_{3}\right)$ secara bersama-sama mempunyai pengaruh yang positif dan signifikan terhadap kunjungan wisatawan ke objek wisata syariah Sumatera Barat. Hal ini berarti kunjungan wisatawan ke objek wisata syariah Sumatera Barat dipengaruhi oleh promosi terhadap objek wisata, kemudian pelayanan yang baik terhadap wisatawan yang akan menimbulkan kepuasan tersendiri terhadap wisatawan saat berkunjung ke objek wisata syariah di Sumatera Barat.

\section{Implikasi Penelitian}

Berdasarkan analisa data mengenai pengaruh variabel $\operatorname{promosi}\left(\mathrm{X}_{1}\right), \quad$ pelayanan $\left(\mathrm{X}_{2}\right)$ dan Kepuasan $\left(\mathrm{X}_{3}\right)$ serta secara individu dan secara bersamaan terhadap kunjungan wisatawan ke objek wisata syariah Sumatera Barat, maka implikasi dalam penelitian ini adalah sebagai berikut:

1. Promosi $\left(\mathrm{X}_{1}\right)$

Variabel promosi $\left(\mathrm{X}_{1}\right)$ tidak berpengaruh signifikan terhadap kunjungan wisatawan ke objek wisata syariah Sumatera Barat dengan nilai regresi sebesar 0,104 atau $10,4 \%$, dan dapat juga dilihat dengan nilai TCR tertinggi pada variabel promositerdapat pada pernyataan Nomor. 6 yaitu "Media cetak dan elektronik sangat membantu dalam mempublikasikan wisata Syariah di Sumatera Barat" dengan nilai TCR sebesar 80,6\%. Berdasarkan nilai TCR tertinggi tersebut dapat disimpulkan bahwa pihak dari Dinas Pariwisata Provinsi Sumatera Barat Sendiri harus lebih giat lagi meningkatkan promosi terhadap pariwisata syariah di Sumatera Barat baik melalu media cetak maupun melalui media elektronik.

Selanjutnya dapat dilihat juga pada nilai TCR terendah pada variabel promositerdapat pada pernyataan Nomor. 4 yaitu "Saya merasa senang dan ingin terus berkunjung ke objek wisata syariah di Sumatera Barat karena adanya promosi penjualan yang memberikan hadiah pada event-event tertentu" dengan nilai TCR sebesar 70\%. Berdasarkan nilai TCR terendah tersebut dapat diambil kesimpulan bahwa pihak pengelola wisata dalam hal ini Dinas Pariwisata Sumatera Barat harus membuat event-event yang bisa membangkitkan gairah pengunjung agar tetap selalu 
Jurnal Manajemen dan Kewirausahaan, Volume 8, Nomor 1, Januari 2016

ISSN 2086 - 5031

mengunjungi wisata syariah di Sumatera Barat.

2. Pelayanan $\left(\mathrm{X}_{2}\right)$

$$
\text { Variabel Pelayanan }\left(\mathrm{X}_{2}\right)
$$

berpengaruh signifikan terhadap kunjungan wisatawan ke objek wisata syariah Sumatera Baratdengan nilai regresisebesar $\quad 0,247$ atau $24,7 \%$,dan dapat juga dilihat dengan nilai TCR tertinggi pada variabel pelayananterdapat pada pernyataan Nomor. 6 yaitu "Pengunjung merasa aman dan nyaman dengan kunjungan yang mereka lakukan ke objek wisata syariah Sumatera Barat" dengan nilai TCR sebesar81,6\%. Berdasarakann nilai TCR tertinggi tersebut dapat disimpulkan bahwa perlu mempertahankan tingkat pengamanan serta meningkatkan fasilitas supaya pengunjung lebuh aman dan nyaman lagi berkunjung kepariwisata syariah di Sumatera Barat .

Selanjutnya dapat juga dilihat pada nilai TCR terendah pada variabel pelayananterdapat pada pernyataan Nomor. 3 yaitu "Karyawan dan masyarakat di objek wisata syariah Sumatera Barat cepat tanggap terhadap kesulitan-kesulitan yang dihadapi oleh pengunjung" dengan nilai $70,2 \%$. Berdasarkan nilai TCR terendah tersebut dapat diambil kesimpulan bahwa karyawan dan masyarakat disekitar daerah wisata syariah Sumatera Barat harus lebih peka lagi terhadap keluhan dan kesulitankesulitan yang dihadapi pengunjung saat berkunjung ke objek wisata syariah Sumatera Barat.

3. Kepuasan $\left(\mathrm{X}_{3}\right)$

Variabel $\quad \operatorname{kepuasan}\left(\mathrm{X}_{3}\right)$ berpengaruh signifikan terhadap kunjungan wisatawan ke objek wisata syariah Sumatera Baratdengan nilai regresisebesar $\quad 0,597$ atau $59,7 \%$,dan dapat juga dilihat dengan nilai TCR tertinggi pada variabel kepuasanterdapat pada pernyataan Nomor. 7 yaitu“Pemandangan di sekitar objek wisata sangat indah dan sejuk sesuai dengan yang diharapkan dan sesuai dengan yang dikatakan orang lain" dengan nilai TCRsebesar $82,4 \%$. Berdasarkan nilai TCR tersebut dapat diambil kesimpulan bahwa dengan kondisi yang seperti ini pihak pengelola harus tetap menjaga kelestarian tempat serta merawatnya agar tetap asri, sehingga tetap menyejukkan mata dan fikiran saat berkunjung ke objek wisata syariah tersebut.

Selanjutnya dapat juga dilihat pada nilai TCR terendah pada variabel kepuasanterdapat pada pernyataan 
Jurnal Manajemen dan Kewirausahaan, Volume 8, Nomor 1, Januari 2016

ISSN 2086 - 5031

Nomor. 5 yaitu "Fasilitas dan sarana yang ada di objek wisata syariah Sumatera Barat lengkap dan membuat saya tidak ingin berkunjung ke objek wisata lain" dengan nilai TCR sebesar 70,6\%. Berdasarkan nilai TCR terendah tersebut dapat diambil kesimpulan bahwa pihak pengelola harus lebih meningkatkan fasilitas, sarana dan prasarana di objek wisata syariah yang dapat memanjakan pengunjung objek wisata tersebut.

\section{KESIMPULAN DAN SARAN}

\section{Kesimpulan}

Berdasarkan penelitian yang telah dilakuakan pada variabel promosi $\left(\mathrm{X}_{1}\right)$, pelayanan $\left(\mathrm{X}_{2}\right)$ dan kepuasan $\left(\mathrm{X}_{3}\right)$ terhadap kunjungan wisatawan ke objek wisata syariah Sumatera Barat, ditemukan 2 (dua) variabel berpengaruh signifikan dan 1 (satu) variabel tidak berpengaruh signifikan terhadap keputusan berkunjung diantaranya adalah sebagai berikut:

1. Promosi $\left(\mathrm{X}_{1}\right)$ tidak berpengaruh signifikan terhadap keputusan berkunjung ke objek wisata syariah Sumatera Barat dengan pengaruhnya sebesar 0,104 atau $10.4 \%$. nilai $t_{\text {hitung }}>t_{\text {tabel }}(1,070<$ 1,660), dengan signifikan 0,287 atau lebih besar dari level of significant $(\alpha) \quad 0,05 \quad$ sehingga keputusannya, maka Ho diterima dan $\mathrm{H}_{1}$ ditolak.

2. Pelayanan $\left(\mathrm{X}_{2}\right)$ berpengaruh signifikan terhadap keputusan berkunjung ke objek wisata syariah Sumatera Barat dengan pengaruhnya sebesar 0,247 atau $24,7 \%$. Nilai $t_{\text {hitung }}>t_{\text {tabel }}$ $(3,276>1,660)$, dengan signifikan 0,01 atau lebih kecil dari level of significant $(\alpha) \quad 0,05$ sehingga keputusannya, maka Ho ditolak dan $\mathrm{H}_{2}$ diterima.

3. Kepuasan $\left(\mathrm{X}_{3}\right)$ berpengaruh signifikan terhadap keputusan berkunjung ke objek wisata syariah Sumatera Barat dengan pengaruhnya sebesar $\quad 0,597$ atau $59,7 \%$. Nilai $t_{\text {hitung }}>t_{\text {tabel }} \quad(5,723>$ 1,660), dengan signifikan $\quad 0,000$ atau lebih kecil dari level of significant $(\alpha) \quad 0,05 \quad$ sehingga keputusannya, maka Ho ditolak dan $\mathrm{H}_{3}$ diterima.

4. Variabel promosi $\left(\mathrm{X}_{1}\right)$ dan variabel pelayanan $\left(\mathrm{X}_{2}\right)$ dan variabel kepuasan $\left(\mathrm{X}_{3}\right)$ secara bersama-sama berpengaruh signifikan terhadap kunjungan wisatawan ke objek wisata syariah Sumatera Barat. Dimana 
Jurnal Manajemen dan Kewirausahaan, Volume 8, Nomor 1, Januari 2016

ISSN 2086 - 5031

nilai $\mathrm{F}_{\text {hitung }}>\mathrm{F}_{\text {tabel }}$ atau62,544 >

2.70, dan tingkat signifikan

$0,000<0,05$ atau lebih kecil dari

level of significant ( $\alpha) \quad 0,005$

sehingga keputusannya, maka Ho

ditolak dan Ha diterima.

\section{Saran}

Dari permasalahan yang telah dikemukakan sebelumnya mengenai faktor-faktor yang mempengaruhi kunjungan wisatawan ke objek wisata syariah Sumatera Barat, Penulis memberikan sumbangan pemikiran sebagai berikut :

1. Untuk dapat lebih meningkatkan promosi terhadap wisatawan untuk berkunjung ke objek wisata syariah Sumatera Barat, dan perusahaan atau pihak manajemen juga harus memperhatikan faktorfaktor lain yang mempengaruhi keputusan kunjungan wisatawan.

2. Sebaiknya pihak pengelola dan Dinas Pariwisata Sumatera Barat terus melakukan evaluasai dengan cara meningkatkan promosi serta pelayanan terhadap pengunjung/konsumen agar keputusan berkunjung ke objek wisata syariah Sumatera Barat lebih meningkat.
3. Bagi peneliti selanjutnya penulis menyarankan agar memperbanyak jumlah responden yang akan digunakan serta dilakukan dengan rentang waktu yang lebih lama. Hal ini perlu dilakukan agar hasil yang ditemukan dalam penelitian tersebut akan lebih baik dari penelitian ini.

\section{DAFTAR PUSTAKA}

Arikunto, Suharsimi. (2010). Prosedur Penelitian, Suatu Pendekatan Praktek. Jakarta: Rineka Cipta.

Hasan, Iqbal. (2010). Pokok-Pokok Materi Statistik 2. Jakarta:Bumi Aksara

Kotler, Gary Amstrong. (2013). PrinsipPrinsip Pemasaran. Jilid 3. Jakarta:Erlangga

Kotler, Philip and Kevin Lane Keller. (2009).Manajemen Pemasaran. Edisi 13 jilid 2. Jakarta: Erlangga

Kotler, Philip and Kevin Lane Keller. (2009).Manajemen Pemasaran. Edisi 12 jilid I . Jakarta:Indeks

Kotler, Philip. (2010). Manajemen Pemasaran Indonesia. Jakarta:Indeks.

Saputra, Riyan. (2015). FaktorFaktor Yang Mempengaruhi Kunjungan Wisatawan Objek Wisata Museum Adityawarman Di Kota Padang.

Sekaran, Umar. (2006) Research Methods For Business Metodologi Penelitian Untuk Bisnis. Edisi 4, Salemba Empat:Jakarta

Sofyan, BSEE, MBA Riyanto. (2012). Prospek Bisnis Pariwisata Syariah. Jakarta: Republika. 
Jurnal Manajemen dan Kewirausahaan, Volume 8, Nomor 1, Januari 2016 ISSN 2086 - 5031

Sugiarti, Ariqa Nurwila. (2015). Strategi Pengembangan Pariwisata Syariah Untuk Meningkatkan Kunjungan Wisatawan Muslim Domestik Dan Mancanegara Di Kota Bandung .

Sugiyono. (2011). Metode Penelitian Kuantitatif Kualitatif dan $R \& D$. Bandung: Alfabeta.

Sugiyono. (2014). Metode Penelitian Kuantitatif Kualitatif dan $R \& D$. Bandung: Alfabeta.

Sumbarprov. (2016, 06 10). Sumbarprov.

Dipetik $11 \quad 12, \quad 2016$, dari Sumbarprov.go.id: http://www.sumbarprov.go.id/details/ news/9288

Tjiptono. (2012). Pemasaran Strategik. Edisi 1. Yogyakarta: Andi. 